\title{
Aerial and snorkelling census techniques for estimating green turtle abundance on foraging areas: A pilot study in Mayotte Island (Indian Ocean)
}

\author{
David Roos ${ }^{1, a}$, Dominique Pelletier ${ }^{2}$, Stéphane Ciccione ${ }^{3}$, Marc Taquet ${ }^{1}$ and George Hughes ${ }^{4}$ \\ 1 Laboratoire Ressources Halieutiques, Ifremer, BP 60, 97822 Le Port Cedex, France \\ 2 Laboratoire MAERHA, IFREMER, BP 21105, 44311 Nantes Cedex 3, France \\ 3 Centre d'Étude et de Découverte des Tortues Marines de La Réunion, BP 40, 97898 St-Leu Cedex, France \\ 44 Thorngate Road Pietermaritzburg 3201, South Africa
}

Received 23 July 2004; Accepted 8 June 2005

\begin{abstract}
Monitoring the abundance of green turtles (Chelonia mydas) is necessary to assess population trends and risks of collapse. This note presents a study aimed at comparing three techniques for the direct estimation of green turtle numbers in their foraging habitats (seagrass beds and reef flats). The experiment was carried out at Mayotte Island, Western Indian Ocean. The techniques involved were surveys by snorkel, and aerial surveys using a microlight aircraft and a paramotor. Each technique had shortcomings and advantages. While each technique provided estimations of turtle numbers only surveys by snorkel permitted identification of species and sex, whenever visibility and turtle behaviour permitted. Along the shorelines, and over foraging areas, the paramotor was found to be most suitable for direct estimations of turtle numbers. The major advantage of this technique lied in its capability to obtain a synoptic snapshot of turtle distribution over foraging areas. Linear surveys from a microlight aircraft are better suited to monitor foraging areas located further away from the shore.
\end{abstract}

Key words: Green turtle / Chelonia mydas / Abundance estimation / Aerial survey / Snorkelling survey / Foraging habitats

Résumé - Observations aériennes et marines pour l'évaluation de l'abondance des tortues marines sur les aires d'alimentation : une étude pilote à l'île de Mayotte. Le suivi de l'abondance de tortues vertes (Chelonia mydas) est nécessaire pour évaluer l'évolution et éventuellement, le risque d'extinction des populations. L'objectif de cette expérience est de comparer trois techniques d'observation permettant l'évaluation directe de l'abondance totale de tortues vertes sur les aires d'alimentation (herbiers et platiers récifaux). L'étude a été conduite à l'île de Mayotte (ouest de l'océan Indien). Les techniques testées sont le comptage sous-marin et les comptages aériens à partir d'un ultra léger motorisé (ULM) et d'un paramoteur. Les limites de chaque technique utilisée ont été mises en évidence. L'abondance totale des tortues a été estimée par les trois techniques. Seuls, les comptages sous-marins ont permis de préciser des caractéristiques biologiques tels que l'espèce et le sexe, lorsque les conditions de visibilité et le comportement des tortues le permettaient. Le paramoteur paraît le plus adapté pour une estimation directe de l'abondance sur les aires d'alimentation situées à proximité immédiate de la côte. Cette technique permet de disposer d'un état de la répartition des tortues sur les aires d'alimentation à un moment donné. Pour les zones d'alimentation plus éloignées de la côte, l'usage de l'ULM est nécessaire pour réaliser les comptages à partir de transects linéaires.

\section{Introduction}

On a global and regional level most species of marine turtle are classified as endangered by international conservation bodies such as the World Conservation Union (IUCN) and conventions such as the Biodiversity Convention, Convention on International Trade in Endangered Species of Wild Flora and Fauna (CITES) and the Convention on Migratory Species

\footnotetext{
a Corresponding author: david.roos@ifremer.fr
}

(Hykle 1999). Turtle populations are subject to many threats from human activities, resulting in direct mortality (e.g. poaching or incidental catch), or indirect through habitat transformation or destruction (e.g. nesting sites or feeding sites) (Gibson and Smith 1999; Oravetz 1999). Monitoring marine turtle status through population estimates is therefore essential. Likewise it is important to record and describe turtle foraging sites to ensure the protection of threatened populations at all life stages. 


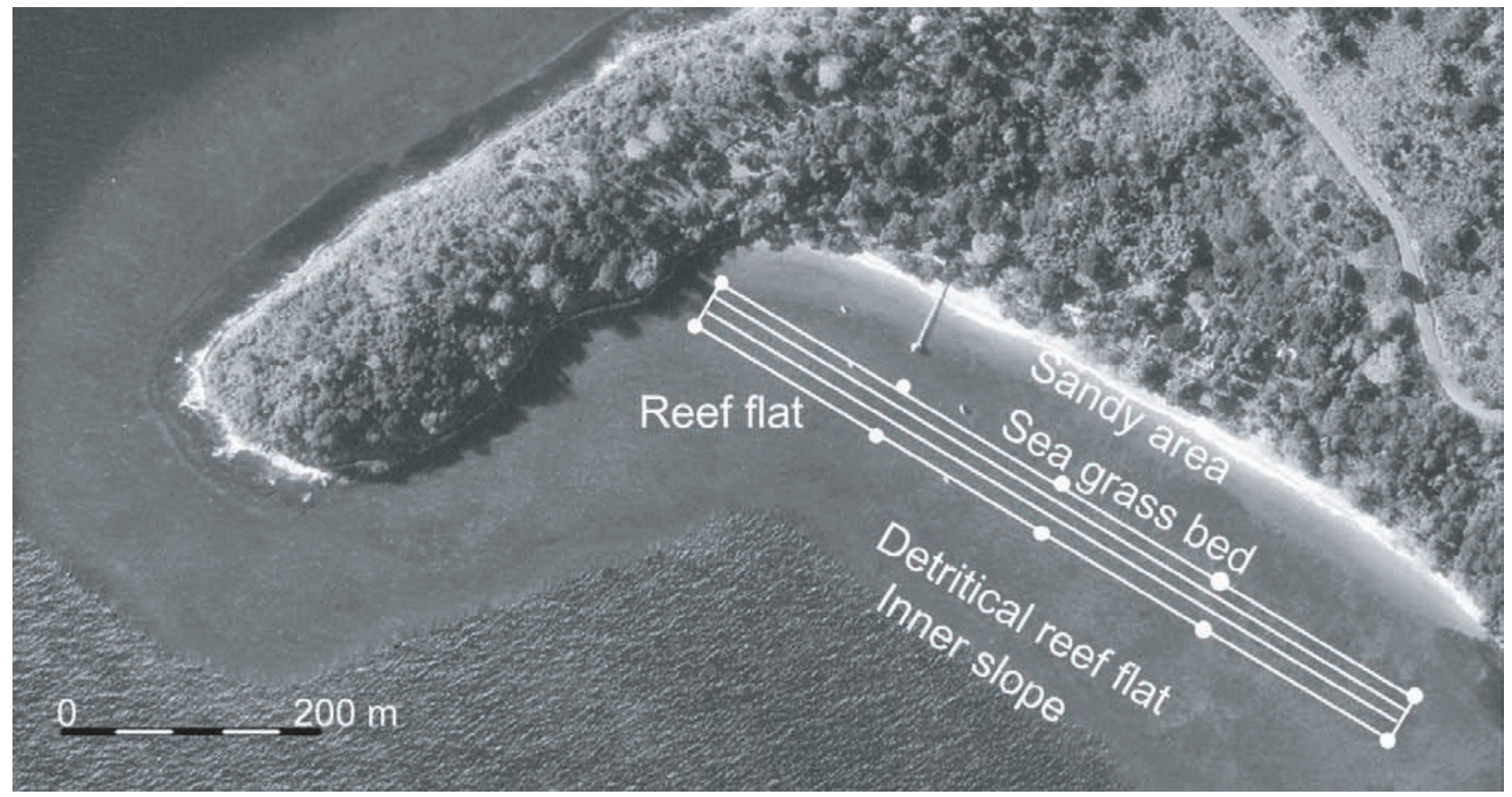

Fig. 1. Transect line on N'Gouja sea grass bed. Buoys were materialized by dots.

The dynamics of sea turtle ecology makes it difficult to estimate overall population abundance. Juvenile turtles are pelagic, disperse over wide areas and are difficult to find in the sea. However at nesting sites and seagrass foraging sites it is possible to obtain meaningful and valuable censuses. For example, the numbers of adult females on nesting beaches may be estimated from nest counts or track counts (Le Gall et al. 1986; Mortimer 1988; Gerrodette and Taylor 1999), markrecapture techniques (Le Gall et al. 1986; Reese and Welsh 1998; Heppell et al. 1996), or aerial track surveys (Meylan et al. 1985; Fritz et al. 1982; Crouse 1984).

The numbers of foraging sea turtles in shallow waters has been estimated from aerial surveys (Epperly et al. 1995a,b; Braun and Epperly 1996; Shoop and Kenney 1992; Fritts et al. 1983; Schroeder and Thompson 1987; Sauvignet et al. 2000). Most recorded estimations of foraging sea turtles were obtained by extrapolating from the number of sea turtles observed on the surface. Without any count of the proportion of the turtles that were unobservable, i.e. below the water, the results obtained were of limited value.

In this note, we reported the results of a study comparing three census techniques to directly count the total number of green turtles (Chelonia mydas) in selected foraging habitats. We described the techniques, discussed the results, and provided recommendations for future projects in terms of sampling design and census techniques.

\section{Material and methods}

\subsection{Census site}

The census was conducted at Mayotte Island (12 50 ' $\mathrm{S}$, $\left.45^{\circ} 10^{\prime} \mathrm{E}\right)$, Western Indian Ocean. Mayotte Island is a major nesting site and, due to the presence of extensive seagrass beds which cover some $100 \mathrm{~km}^{2}$ (Frazier 1985), an important foraging site. Foraging areas include both coral reefs and seagrass beds and are located in the shallow waters of the lagoon (less than $5 \mathrm{~m}$-deep). The census was carried out in September 2002 on the N'Gouja seagrass bed (located in the south of the main island) where both snorkelling and aerial surveys were conducted along a predetermined transect near the shoreline (Fig. 1). The transect was $640 \mathrm{~m}$ long and divided into three 12 m-wide contiguous strips (Fig. 1). The strip width was determined by the minimum underwater visibility, thus ensuring that all turtles present in the transect could be seen. Ten buoys delineated the surface of the survey area, which totalled $23040 \mathrm{~m}^{2}$ (Fig. 1).

\subsection{Visual counts from snorkel diving}

Visual count techniques are commonly used for fish communities (Sale 2002), yet few were used for marine turtles (Bjorndal and Bolten 2000). In this study visual counts were collected by two surface swimmers, swimming slowly at the same speed and moving in the same direction (Fig. 2). Swimmers were linked by a $12 \mathrm{~m}$-long rope, to ensure parallel trajectories, and a compass was used to maintain their direction. While each swimmer surveyed one side strip, both of them monitored the central strip. Each transect was covered within thirty minutes.

After each survey the overall number of turtles was calculated by summing the counts on the two side strips and the maximum number recorded in the central strip. Recorded sightings in the central strip were also used to estimate differences between observers. 


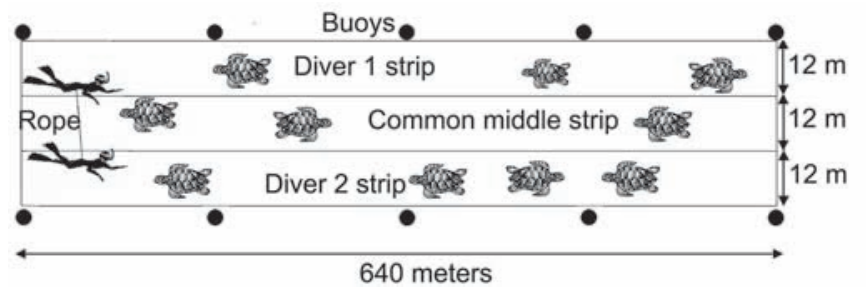

Fig. 2. Description of snorkelling surveys.

When external sexual characteristics were apparent (Wibbels 1999), the sex of each adult was recorded as male or female. Sex was classified as undetermined in all other cases. Data were recorded per longitudinal section of the transect.

\subsection{Aerial counts}

Aerial counts were recorded from a microlight aircraft and a paramotor.

The microlight aircraft was a 3 axe, sky Ranger bi-place plane (Best Of, Inc.) with a 80 HP Jabiru engine. The plane flew at a constant altitude of $150 \mathrm{~m}$, and at a speed of ca. $80 \mathrm{~km} \mathrm{~h}^{-1}$. It closely followed the middle strip of the ground transect. The crew consisted of a pilot and an experienced marine turtle observer, who recorded the total number of turtles observed within the transect area (surface and bottom). The transect was covered within $30 \mathrm{~s}$.

The paramotor was a $42 \mathrm{~m}^{2}$ bi-place airfoil wing, with a $21 \mathrm{HP}$ engine. The wing flew at a constant altitude of $150 \mathrm{~m}$ and at a speed of less than $30 \mathrm{~km} \mathrm{~h}^{-1}$ (depending on wind strength). Under these conditions, the paramotor flight time was roughly $1 \mathrm{~h} 30 \mathrm{~min}$. The observer was located ahead of the pilot. The angle of vision allowed the observer to count within a $500 \mathrm{~m}$-wide corridor, determined by georeferenced points located on the reef flats. In the lagoon at Mayotte Island, the inner reef flats did not exceed the width of that corridor. Therefore, a single flight was sufficient to count the total number of turtles in this area.

\subsection{Census design and estimation method}

Microlight aircraft and snorkelling observations started simultaneously to limit environmental variations linked to tide, human activity and sun position. Nine microlight surveys and twenty snorkelling counts were carried out. Whenever possible, the area was surveyed twice a day, in the morning and in the afternoon.

Transects were surveyed at different times of the tidal cycle. Tidal height was measured to take into consideration the influence of tide on turtle movements. Sea elevation was corrected to the reference level in marine maps.

In the case of the paramotor, one flight was carried out during the same period as snorkelling and microlight aircraft counts whilst eleven other grazing sites were also surveyed (Fig. 3). In each surveyed site, the observed numbers of green turtles was recorded from the reef flat, which included the sandy area, the seagrass bed and the detritus reef flat up to

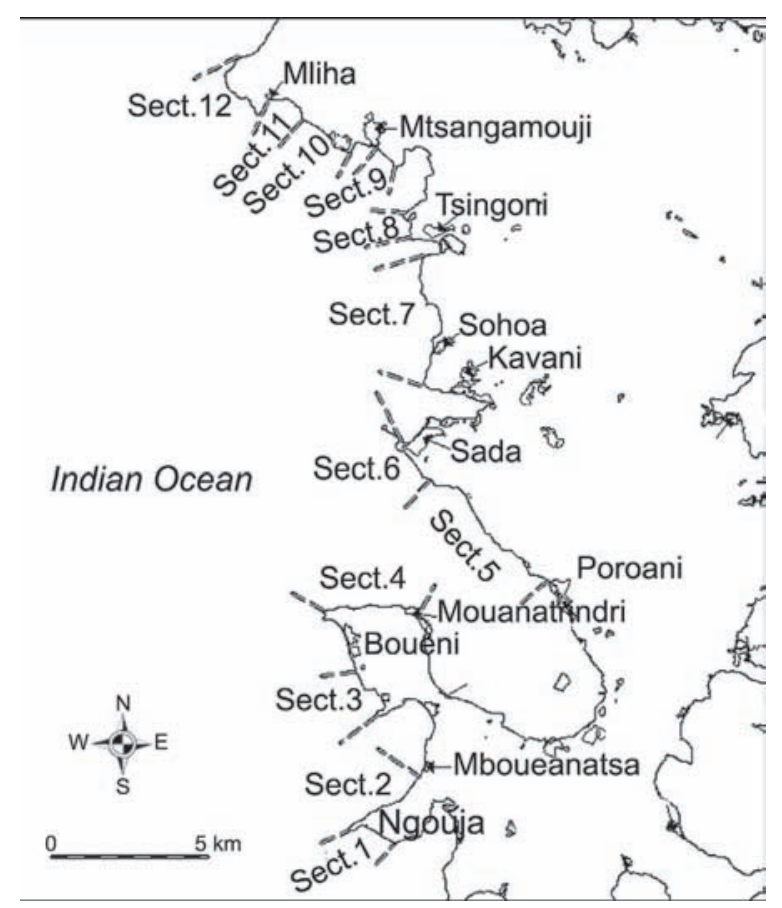

Fig. 3. Coast sections surveyed by the paramotor at Mayotte Island.

the inner slope (Fig. 1). For each of the 12 sites, the surface of the surveyed area was estimated from an aerial image (“Orthonum ${ }^{\circledR}$ IGN-1997", http: //www . ore-oi .org) using the MAPINFO ${ }^{\circledR}$ software.

The mean number of turtles and corresponding mean density (number of turtle per $\mathrm{m}^{2}$ ) were calculated for each census technique. Non parametric Mann-Whitney tests were used to test for differences between observers, and between census techniques.

Between-site differences in turtle numbers and densities obtained from the paramotor could not be statistically tested because only one count was available per site.

\section{Results and discussion}

\subsection{Numbers observed during snorkelling surveys and aerial surveys}

\section{Snorkel census}

In the twenty snorkelling surveys, the two observers counted 462 turtles. Counts recorded in the central strip showed no significant differences between observers $(U=$ 196.5 Mann-Whitney; $p>0.05$ ). Sex could be determined for $86 \%$ of turtles, among which $52 \%$ were males and $48 \%$ were females. Along any given transect, turtles were generally found in small groups of 4 or 5 individuals. Individuals appeared to be randomly distributed with no marked associations based on size or sex. 


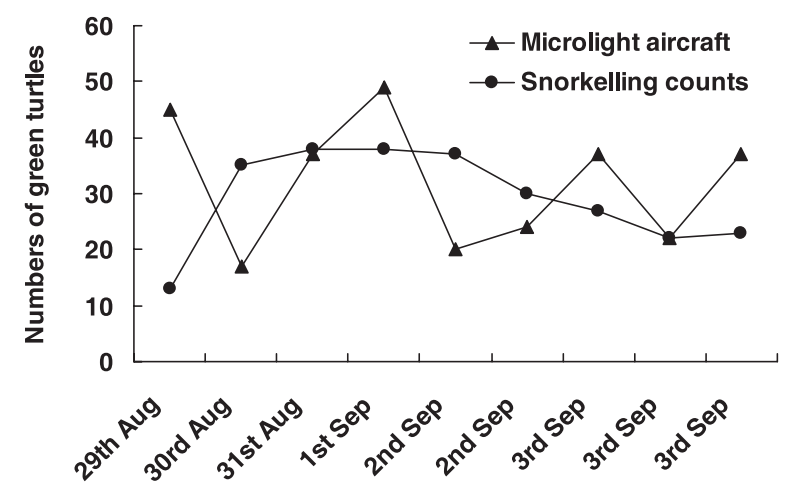

Fig. 4. Comparison of microlight aircraft and snorkelling surveys.

\section{Microlight census}

In the microlight aircraft counts, 288 green turtles were observed although the technique proved to be inadequate in counting or even recording groups and in addition, sex and size could not be determined.

With these two techniques, recorded numbers varied from day to day (Fig. 4).

The mean number and mean density per day estimated from the microlight aircraft were 32 individuals and 0.0014 ind. $\mathrm{m}^{-2}$ with a coefficient of variation $(\mathrm{CV})$ of $34 \%$.

The snorkelling surveys gave a mean number of 29 individuals and a mean density of 0.0013 ind. $\mathrm{m}^{-2}, C V=31 \%$. The mean values obtained from the two techniques were not significantly different ( $U=37$, Mann-Whitney, $p>0.05$ ). Mean numbers obtained from the two techniques were not significantly different ( $U=37$, Mann-Whitney, $p>0.05$ ).

We also investigated the relationship between turtle number and water depth. In preliminary observations, turtles were found to occupy the seagrass bed only when water depth exceeded $0.9 \mathrm{~m}$. When the water level was too low, green turtles appeared to prefer the inner reef slope (Fig. 1). During all censuses water depth ranged from 1.2 to $2.7 \mathrm{~m}$. Results showed that in these conditions, no significant effect of water depth upon green turtle abundance could be observed. Thus, counts should only be conducted when water depth exceeds $1 \mathrm{~m}$.

\subsection{Turtle numbers from the paramotor}

The paramotor was used to carry out two counts along the transect and to estimate the overall numbers of turtles over the whole area (reef flat including sea grass beds). Counts took place on the same day with 21 and 26 turtles being observed in the transect surveys, corresponding to an average of 23.5 individuals and a density of 0.0012 ind. $\mathrm{m}^{-2}$.

In addition, in the whole reef flat a total of 188 turtles were recorded during the same flights corresponding to a density of $2.97 \times 10^{-4}$ ind. $\mathrm{m}^{-2}$. The density in the transect area is thus much higher than in the rest of N'Gouja, suggesting that seagrass beds are a preferred foraging habitat for green turtles.

Results obtained on 12 grazing sites showed differences in densities between sites (Table 1, Fig. 3). N'Gouja and the
Table 1. Estimated reef flat surface, abundance and density of green turtles observed from the paramotor on 12 sites of Mayotte Island (Fig. 3). Map sections may be identified from Figure 2. N'Gouja corresponds to Sect. 1 .

\begin{tabular}{crccc}
\hline $\begin{array}{c}\text { Map } \\
\text { Sections }\end{array}$ & $\begin{array}{c}\text { Reef flat } \\
\text { surface }\left(\mathrm{m}^{2}\right)\end{array}$ & $\begin{array}{c}\text { Abundance } \\
\text { (ind.) }\end{array}$ & $\begin{array}{c}\text { Density } \\
\left(10^{-4} \text { ind.m }{ }^{-2}\right)\end{array}$ & $\begin{array}{c}\text { Rank in } \\
\text { terms of } \\
\text { density }\end{array}$ \\
\hline 1 & 634000 & 188 & 2.97 & 1 \\
2 & 712000 & 138 & 1.94 & 3 \\
3 & 650000 & 27 & 0.41 & 11 \\
4 & 1000000 & 43 & 0.43 & 10 \\
5 & 1470000 & 19 & 0.13 & 12 \\
6 & 110000 & 172 & 1.56 & 4 \\
7 & 1600000 & 109 & 0.68 & 9 \\
8 & 1100000 & 43 & 0.84 & 7 \\
9 & 510000 & 40 & 0.78 & 8 \\
10 & 760000 & 73 & 0.96 & 6 \\
11 & 420000 & 59 & 1.40 & 5 \\
12 & 637000 & 186 & 2.92 & 2 \\
\hline
\end{tabular}

Milha site (Sect. 12, Fig. 3) exhibited by far the largest densities and appeared as important grazing sites for green turtles. Yet, both sites experience a relatively high level of human disturbance; N'Gouja has a large hotel, and Milha is close to a village. In contrast, some of the other sites are rarely or never visited.

The large number of green turtles observed in our study suggests that Mayotte Island is an important foraging site in the western Indian Ocean. Comparisons with other sites would be invaluable in ascertaining whether Mayotte is normal or exceptional.

There was no significant relationship between the reef flat surface area and turtle density, and the preference of turtles for seagrass beds seen in N'Gouja suggest that habitat preferences should be accounted for when designing research protocols. For instance, stratifying design according to reef characteristics would improve the accuracy of density estimates. In this respect, measurements of habitat such as reef area characteristics, coverage of living organisms and substratum compositions would be useful to investigate the relationships between turtle abundance and habitat features, and to explain differences in numbers observed between sites.

\section{Conclusion: Which census technique for foraging sea turtles?}

The techniques used in the experiment have both disadvantages and advantages in estimating the numbers of foraging green turtles.

Snorkelling surveys allow a simultaneous evaluation of turtle abundance and characteristics e.g. species, sex as well as length (not recorded here). However, the size of the surveyed area and the number of observations are limited by an observer's swimming capability in terms of speed and endurance and by variability in underwater visibility. Snorkelling observations are also likely to be affected by the influence of human observers on the turtles. In this respect, N'Gouja may be unique because turtle behaviour seemed to be unaffected 
by human presence. This may not be the case in other foraging sites. Unpublished observations from the authors show that in other locations foraging green turtles generally avoided observers. Aerial counts by the microlight aircraft and paramotor are less likely to affect the behaviour of foraging turtles. At times the shadow of the plane or wing on the surface of the water appeared to cause turtles on the surface to dive slowly whilst remaining visible in the clear shallow waters.

The microlight aircraft flights yielded frequency estimates but species, sex and size of turtles could not be ascertained. Due to the speed and altitude of the plane there is also a risk (not negligible) of confounding turtles with substrata like coral patches. Although the microlight may be used to survey large areas for qualitative purposes (Henwood and Epperly 1999), its speed is too high to provide reliable counts in the sea. In contrast, the microlight aircraft may be more useful to provide other frequency indices like track counts of nesting turtles on beaches (Crouse 1984; Schroeder and Murphy 1999). The authors are currently using a microlight aircraft for this purpose on several Mayotte beaches.

In comparison with the microlight aircraft, the paramotor had several advantages: a low speed, the possibility of hovering and an ease of changing altitude to adjust the count to the width of reef flat, and finally a better position for the observer on the airfoil wing. These advantages allowed species to be identified and counts to be more precise. The manoeuvrability of the paramotor made it possible to count the total number of turtles in a zone larger than the transect area. However, the paramotor is sensitive to meteorological conditions, and must be used close to the coastline because of its limited fuel capacity. Mayotte Island seagrass beds located close to the barrier reefs could not be safely surveyed from the paramotor.

The major advantage of the paramotor remains in its capability to obtain both a synoptic picture of turtle distribution over seagrass beds and reef flats, and a more accurate estimation of numbers.

Given the results of this pilot study, we recommend that future monitoring of sea turtles on foraging areas includes the following features:

1) Definition of habitats for mapping and design of sampling sites;

2) Paramotor aerial surveys to estimate the spatial distribution and abundance of turtles, and when possible;

3) Snorkelling surveys to identify sex and estimate animal size; in the case of seagrass beds located further from shore, surveys from the microlight aircraft are needed.

\footnotetext{
Acknowledgements. The authors thank two anonymous reviewers for their numerous and constructive comments. This paper is a part of a sea turtle study and conservation project in Mayotte. The project was funded by the Collectivité Départementale de Mayotte, the Direction de la Forêt (DAF), the Centre d'Étude et de Découverte des Tortues Marines (CEDTM) and IFREMER. The authors particularly thank Caroline Guillaume, Daniel Lesur, Mireille Quillard, Ali Mari and Colette Robbe for their dedication and availability.
}

\section{References}

Bjorndal K.A., Bolten A.B., 2000, Proceedings of a workshop on assessing abundance and trends for in-water sea turtle populations. NOAA Technical Memorandum NMFS-SEFSC-445.

Braun J., Epperly S.P., 1996, Aerial surveys for sea turtles in Southern Georgia waters, June, 1991. Gulf Mexico Sci. 14, 39-44.

Crouse D.T., 1984, Loggerhead sea turtle nesting in North Carolina: Applications of an aerial survey. Biol. Conserv. 29, 143-155.

Epperly S.P., Braun J., Chester A.J., 1995a, Aerial surveys for sea turtles in north Carolina inshore waters. Fish. Bull. 93, 254-261.

Epperly S.P., Braun J., Chester A.J., Cross F.A., Merriner J.V., Tester P.A., 1995b, Winter distribution of sea turtles in the vicinity of Cape Hatteras and their interactions with the summer flounder trawl fishery. Bull. Mar. Sci. 56, 547-568.

Frazier J., 1985, Marine turtles in the Comoros Archipelago. Amsterdam, North Holland.

Fritts T.H., Hoffman W., McGehee M.A., 1983, The distribution and abundance of marine turtles in the Gulf of Mexico and nearby Atlantic waters. J. Herpetol. 17, 327-344.

Fritz T.H., Stinsin M.L., Marquez M.R., 1982, Status of sea turtle nesting in southern Baja California, Mexico. Bull. South. Calif. Acad. Sci. 81, 51-60.

Gerrodette T., Taylor B.L., 1999, Estimating population size. In: Eckert K.L., Bjorndal K.A., Abreu Grobois F.A., Donnelly M. (Eds.). Research and management techniques for the conservation of sea turtles, pp. 67-71. IUCN/SSC Marine Turtle Specialist Group Publication.

Gibson J., Smith G., 1999, Reducing threats to foraging Habitats. Research and management techniques for the conservation of sea turtles. In: Eckert K.L., Bjorndal K.A., Abreu Grobois F.A., Donnelly M. (Eds.). Research and management techniques for conservation of sea turtles, pp. 184-188. IUCN/SSC Marine Turtle Specialist Group Publication.

Henwood T.A., Epperly S.P., 1999, Aerial surveys in foraging habitats. In: Eckert K.L., Bjorndal K.A., Abreu Grobois F.A., Donnelly M. (Eds.). Research and management techniques for conservation of sea turtles, pp. 65-66. IUCN/SSC Marine Turtle Specialist Group Publication.

Heppell S.S., Limpus C.J., Crouse D.T., Frazer N.B., Crowder L.B., 1996, Population model analysis for the loggerhead sea turtle, Caretta caretta, in Queensland. Wildl. Res. 23, 143-159.

Hykle D., 1999, International conservation treaties. In: Eckert K.L., Bjorndal K.A., Abreu Grobois F.A., Donnelly M. (Eds). Research and management techniques for conservation of sea turtles, pp. 228-231. IUCN/SSC Marine Turtle Specialist Group Publication.

Le Gall J.Y., Bosc P., Chateau D., Taquet M., 1986, An estimation of the number of adult females of green turtles Chelonia mydas per nesting season at Tromelin and Europa (Indian Ocean) (19731985). Oceanogr. Trop. 21, 3-22.

Meylan A., Meylan P., Ruiz A., 1985, Nesting of Dermochelys coriacea in Caribbean Panama. J. Herpetol. 19, 293-297.

Mortimer J.A., 1988, Green turtle nesting at Aldabra atoll Population estimates and trends. Biol. Soc. Wash. 8, 116-128.

Oravetz C.A., 1999, Reducing Incidental catch in fisheries. Research and management techniques for the conservation of sea turtles. In: Eckert K.L., Bjorndal K.A., Abreu Grobois F.A., Donnelly M. (Eds.). Research and management techniques for the conservation of sea turtles, pp. 189-193. IUCN/SSC Marine Turtle Specialist Group Publication.

Reese D.A., Welsh H.H. Jr., 1998, Comparative demography of Clemmys marmorata populations in the Trimity river of California in the context of Dam-induced alterations. J. Herpetol. $32,505-515$. 
Sale P.F., 2002, Coral reef fishes, Elsevier Science.

Sauvignet H., Pavitrin A., Cicionne S., Roos D., 2000, Premiers résultats des campagnes de dénombrements aériens des tortues marines sur la côte ouest de La Réunion. Bull. Phaeton. 11, 8-18.

Shoop, C.R., Kenney R.D., 1992, Seasonal distributions and abundances of loggerhead and leatherback sea turtles in waters of the northeastern United States. Herpetol. Monogr. 6, 43-67.

Schroeder, B.A., Thompson N.B., 1987, Distribution of the loggerhead turtle, Caretta caretta, and the leatherback turtle, Dermochelys coriacea, in the Cape Canaveral, Florida area: results of aerial surveys. In: W.N. Witzell (Eds.), Ecology of East Florida sea turtles: Proceedings of the Cape Canaveral, Florida, sea turtle workshop, pp. 45-53. US Dep. Commer., NOAA Tech. Rep. NMFS 53.
Schroeder B., Murphy S., 1999, Population surveys (ground and aerial) on nesting beaches. In: Eckert K.L., Bjorndal K.A., Abreu Grobois F.A., Donnelly M. (Eds.). Research and management techniques for the conservation of sea turtles, pp. 45-55. IUCN/SSC Marine Turtle Specialist Group Publication.

Wibbels, T., 1999, Diagnosing the sex of sea turtles in foraging habitats. In: Eckert K.L., Bjorndal K.A., Abreu Grobois F.A., Donnelly M. (Eds.). Research and management techniques for the conservation of sea turtles, pp. 139-143. IUCN/SSC Marine Turtle Specialist Group Publication. 